\title{
Promising varieties of spring glumaceous oat of the mowing and grain-mowing directions, adapted to the natural and climatic conditions of the Volga-Vyatka region
}

\author{
Elena Vologzhanina*, and Galina Batalova \\ Federal Agrarian Scientific Center of the North-East, city of Kirov, 610007, Russian Federation
}

\begin{abstract}
The results of the study of 12 varieties and promising lines of glumaceous oat in the competitive variety testing of the FASC of the North-East (Kirov region) in the period from 2018 to 2020 are presented. The purpose of the research is to assess the productivity, ecological plasticity and stability of the genotypes of glumaceous oat for feed and universal use in the conditions of the Volga-Vyatka region. The dependences of grain yield and dry matter harvesting on the state of agroclimatic resources (HTC), temperature and precipitation are established. The contrasting weather conditions during the years of research allowed to conduct the most complete assessment of the studied genotypes. The most favorable conditions for the formation of a high yield of green mass of oat were formed in $2020\left(\mathrm{I}_{\mathrm{j}}=3.76\right)$, grain - in $2019\left(\mathrm{I}_{\mathrm{j}}=1.35\right)$. The average degree of positive dependence of green mass yield on the height of oat plants was revealed $(\mathrm{r}=0.51)$. The variety of the high-intensity type of the universal direction Medved, promising lines of the mowing direction (178h13 and 245h14) are distinguished.
\end{abstract}

\section{Introduction}

Farming in the Volga-Vyatka region is associated with a rather harsh, unstable nature of natural and climatic conditions (unstable distribution of precipitation and heat by year and territory). That is why oat is of great interest as a highly adaptive crop that can form high, stable yields of grain and green feed in various natural and climatic zones of Russia [1, 2, $3]$. For the northern agricultural territories of the European part of the country and Siberia, only oat is grown from all grain crops for green feed, silage and hay [2].

Oat grain is characterized by a high protein content, a rich composition of vitamins and minerals, as well as good energy properties due to high fat content [4]. Oat for green mass gives more fodder units per hectare than for grain. Thus, $1 \mathrm{f}$.u. of oat grain accounts for 88 $\mathrm{g}$ of digestible protein, and $1 \mathrm{f}$.u. of dry matter $-101 \mathrm{~g}[5,6,7]$.

The variety and soil and climatic conditions have a great influence on the quantity and quality of green feed. In this regard, there is a need to choose varieties of oat of the mowing

\footnotetext{
* Corresponding author: helen.vol@list.ru
} 
and universal direction of use, having high quality and productivity indicators even under stressful conditions [8].

The purpose of the work is a comprehensive assessment of promising varieties and lines of glumaceous oat for feed and universal use, capable of forming stable, high-quality grain yields and green mass in the conditions of the Volga-Vyatka region and to identify highly adaptive, ecologically plastic genotypes that most fully realize their potential in various environmental conditions.

\section{Materials and methods}

The research was carried out in 2018-2020 at the FSBSI FASC of the North-East (Kirov region). 12 promising varieties and lines of glumaceous oat of the nursery of competitive testing included in the State Register of the Russian Federation were studied in accordance with the methodology [9]. The index of environmental conditions $\left(\mathrm{I}_{\mathrm{j}}\right)$, the regression coefficient $\left(\mathrm{b}_{\mathrm{i}}\right)$ and the stability index $\left(\mathrm{S}_{\mathrm{i}}{ }^{2}\right)$ were determined by S.A. Eberhart, W.A. Rassel in the presentation [10], stress resistance according to A.A. Rossielle and J. Hambli [11], the contribution of genotype and environmental conditions to the formation of yield according to N.A. Plokhinsky [12], hydrothermal coefficient (HTC) according to A.I. Selyaninov [13], homeostaticity according to Hi parameters [14], the indicator of the level of variety stability (ILVS/PUSS) according to E.D. Nettevich [15], the indicator of breeding value (Sc) according to V.V. Khangildin [16].

The soil of the experimental site is sod-podzolic medium loamy on the eluvium of Permian clays with a low humus content $(2.43 \ldots 2.91 \%)$ and a $\mathrm{pH}$ value (4.4...5.0), a small humus horizon thickness. Tillage is generally accepted for the Volga-Vyatka region. The mowing of the green mass was carried out in the paniculation phase.

The analysis of agrometeorological conditions during the research period was carried out according to the data of the Kirov Regional Center for Hydrometeorology and Environmental Monitoring. Weather conditions in the years of research were contrasting in terms of precipitation and temperature regime and were characterized by values from close to average long-term to arid and well-moistened. In 2018, excessive moisture was noted, which positively affected the feed productivity of oat. The HTC in the period from germination to paniculation was 2.83. In June, unstable weather was noted, from cold with frequent precipitation to very warm and hot dry weather. The average air temperature was $14.4^{\circ} \mathrm{C}, 85 \mathrm{~mm}$ of precipitation fell during the month $(122 \%$ of the norm). In the first and second decades of the month, waterlogging of the soil was observed. In May 2019, the weather changed from hot to cool with frosts, in June - mostly dry, with occasional heavy showers, the amount of precipitation was $45-70 \mathrm{~mm}$ (65-95\% of the norm). The HTC for the period "sprouting... paniculation" was 1.74 . According to the accumulation of the sum of effective temperatures, the growing season was typical for the region.

The growing season of 2020 was characterized by unstable temperature weather, from very warm to cold, with small, sometimes heavy precipitation in May and June. The sum of effective temperatures in June was $450 \ldots .570^{\circ}$, which is $0.8 \ldots 2.2^{\circ}$ below the climatic norm, the amount of precipitation was $30 \ldots 50 \mathrm{~mm}$ or $45 \ldots 75 \%$ of the norm. In the first half of July, very warm and hot weather prevailed, mostly dry or with small, only occasionally heavy showers. The hydrothermal coefficient (HTC) during the "sprouting - paniculation" period was 1.81. The value of the indicators of the sum of effective temperatures was higher than those in previous years.

For the processing of experimental data, the breeding oriented AGROS software package, version 2.07, and the Microsoft Excel 2007 application software package were used. 


\section{Results and Discussion}

Since the beginning of the shooting phase, a rapid growth of the aboveground organs of oat is noted. By the paniculation phase, oats accumulate the greatest amount of nutrients. During this period, the need of plants for heat and moisture increases [17]. The yield is significantly affected by environmental factors $[3,18]$.

The main indicators of feed productivity of oats are the yield of green mass and the collection of dry matter in combination with grain productivity. The maximum average yield of green mass by genotypes - 28.5 t/ha was formed in 2020 with sufficient precipitation at the beginning of the growing season and warm weather (environmental conditions index $\mathrm{Ii}=3.76)$. Less favorable conditions developed in 2018 ( $\mathrm{Ii}=-3.47)$, the yield of oat green mass was lower by $7.2 \mathrm{t} / \mathrm{ha}$ compared to the indicator of 2020 .

The highest annual average yield of green mass was formed by the lines $178 \mathrm{~h} 13(+19.9$ $\mathrm{t} /$ ha relative to the standard), $245 \mathrm{~h} 14(+4.7 \mathrm{t} / \mathrm{ha}), 325 \mathrm{~h} 12(+3.5 \mathrm{t} / \mathrm{ha})$ and the Medved variety $(+14.7 \mathrm{t} / \mathrm{ha})($ Table 1$)$.

Table 1. The main economically valuable traits of promising varieties of glumaceous oat for green mass, 2018-2020.

\begin{tabular}{|l|c|c|c|c|c|}
\hline Variety, line & $\begin{array}{c}\text { Yield of green } \\
\text { mass, t/ha }\end{array}$ & $\begin{array}{c}\text { Harvesting } \\
\text { of dry } \\
\text { matter, t/ha }\end{array}$ & $\begin{array}{c}\text { Crude } \\
\text { protein, \% }\end{array}$ & Raw fat, \% & $\begin{array}{c}\text { Raw fiber, } \\
\%\end{array}$ \\
\hline $46 \mathrm{~h} 14$ & 24.5 & 5.9 & 9.8 & 2.7 & 29.2 \\
\hline 4 h14 & 22.7 & 4.9 & 10.8 & 2.3 & 30.7 \\
\hline Sapsan & 18.0 & 4.5 & 11.9 & 2.1 & 31.3 \\
\hline Medved & 34.9 & 8.2 & 10.4 & 2.6 & 31.7 \\
\hline 325 h12 & 23.7 & 7.7 & 9.7 & 2.5 & 31.5 \\
\hline Falenets & 20.1 & 5.2 & 10.1 & 2.7 & 28.2 \\
\hline 178 h13 & 40.1 & 7.5 & 10.5 & 2.2 & 31.0 \\
\hline 194 h13 & 22.4 & 6.6 & 10.2 & 2.7 & 30.3 \\
\hline $79 h 14$ & 21.3 & 5.5 & 10.1 & 2.9 & 28.9 \\
\hline 245 h14 & 24.9 & 6.6 & 9.6 & 2.8 & 29.9 \\
\hline Argamak & 24.3 & 6.3 & 12.1 & 2.3 & 29.5 \\
\hline st. Krechet & 20.2 & 5.7 & 11.3 & 2.3 & 29.9 \\
\hline LSD05 & 2.8 & 0.9 & 0.4 & 0.2 & 1.3 \\
\hline
\end{tabular}

In the same genotypes, the maximum values for the harvesting of dry matter were noted - $7.5 \mathrm{t} / \mathrm{ha}, 6.6 \mathrm{t} / \mathrm{ha}, 7.7 \mathrm{t} /$ ha and $8.2 \mathrm{t} / \mathrm{ha}$, respectively. In the Amur region, the yield of oat green mass was 15.6-26.9 t/ha, the collection of dry matter was 2.8-6.0 t/ha; when mowing oats in the phase of mass paniculation [19]. In India, the highest yield of green mass reached $55 \mathrm{t} / \mathrm{ha}$ [20]. In most cases, the yield of green mass and dry matter depends on the height of the plants [21]. In the studied set of genotypes, the height of plants in the paniculation phase varied from 66.8 to $95.6 \mathrm{~cm}$. The maximum level of trait development was noted in the lines $178 \mathrm{~h} 13(95.6 \mathrm{~cm}), 79 \mathrm{~h} 14(90.9 \mathrm{~cm}), 245 \mathrm{~h} 14(91.5 \mathrm{~cm})$. The correlation coefficient of plant height with the yield of green mass and the harvesting of dry matter was average positive ( $\mathrm{r}=0.51$ and $\mathrm{r}=0.47$, respectively).

The digestibility of the feed is affected by the content of protein and fiber in it. With an increase in the amount of protein, the digestibility of protein, fiber and NFES increases, and with an increase in the fiber content decreases.

In genotypes with a high yield of green mass, a decrease in the content of crude protein was observed. The highest percentage of protein was observed in the varieties Argamak (12.1\%), Sapsan (11.9\%) and Krechet (11.3\%). At the same time, the Argamak and Krechet 
varieties have a low percentage of fiber $-29.5 \%$ and $29.9 \%$, respectively, which may indicate a good digestibility of the feed. Low levels of crude fiber content, as well as crude protein, were observed in lines $46 \mathrm{~h} 14,245 \mathrm{~h} 14$. It was found that the percentage of protein content largely depends on the state of agro-climatic resources during the "sproutingpaniculation" period with HTC $(\mathrm{r}=0.77)$, temperature and precipitation $(\mathrm{r}=-0.77)$, as well as a negative relation between the dry matter harvesting index and the fiber content in it $(r=0.52)$ was revealed. Feeds containing a lot of fat have a high energy nutritional value. Significantly high indicators of the yield of green mass and the harvesting of dry matter were combined with an increased fat content of the Medved variety, lines 325h12, 178h13 and $245 \mathrm{~h} 14$. Also, in terms of fat content, the Falenets variety and the lines 79h14, 194h13, $46 \mathrm{~h} 14$ most significantly exceeded the standard. The studies showed a moderately negative relation between the yield of green mass and the fat content in dry matter $(\mathrm{r}=-0.40)$.

The maximum harvesting of dry matter on average by genotypes $(7.6 \mathrm{t} / \mathrm{ha})$ was observed in 2020, which is confirmed by the index of environmental conditions $(\mathrm{Ii}=1.36)$. Less favorable conditions developed in 2018 and 2019, when the index of environmental conditions was negative $(-0.68)$. The highest ecological plasticity in terms of dry matter harvesting was observed in the $325 \mathrm{~h} 12$ line $\left(b_{\mathrm{i}}=3.19\right)$, with low stability of the trait $\left(\mathrm{Si}^{2}=5.63\right)$ (Table 2).

Table 2. Characteristics of ecological adaptability and stability of varieties of glumaceous oat on the basis of "harvesting of dry matter", 2018 ... 2020.

\begin{tabular}{|c|c|c|c|c|c|c|c|c|c|}
\hline \multirow[t]{2}{*}{ Variety, line } & \multicolumn{2}{|c|}{$\begin{array}{l}\text { Harvesting } \\
\text { of dry } \\
\text { matter, t/ha }\end{array}$} & \multirow[t]{2}{*}{$b_{i}$} & \multirow[t]{2}{*}{$\mathrm{Si}^{2}$} & \multirow[t]{2}{*}{$\begin{array}{l}\mathrm{V}, \\
\%\end{array}$} & \multirow[t]{2}{*}{$\begin{array}{c}\text { Resistance } \\
\text { to stress }\end{array}$} & \multirow[t]{2}{*}{$\begin{array}{l}\text { Genetic } \\
\text { flexibilit } \\
\quad y\end{array}$} & \multirow[t]{2}{*}{$\begin{array}{l}\text { ILVS } \\
\text { (PUSS) }\end{array}$} & \multirow[t]{2}{*}{$\mathrm{Sc}$} \\
\hline & $\mathrm{X}_{\text {lim }}$ & $\mathrm{X}_{\mathrm{opt}}$ & & & & & & & \\
\hline $46 \mathrm{~h} 14$ & 4.6 & 6.6 & 0.43 & 2.08 & 19.4 & -2.00 & 5.57 & 134.2 & 4.05 \\
\hline 4h14 & 4.3 & 5.2 & -0.40 & 0.01 & 9.8 & -0.90 & 4.79 & 184.7 & 4.04 \\
\hline Sapsan & 3.7 & 5.1 & 0.10 & 0.98 & 15.8 & -1.40 & 4.43 & 97.2 & 3.27 \\
\hline Medved & 5.1 & 10.4 & 1.57 & 8.50 & 33.7 & -5.27 & 7.74 & 152.6 & 4.05 \\
\hline $325 \mathrm{~h} 12$ & 3.8 & 12.0 & 3.19 & 5.63 & 53.7 & -8.20 & 7.92 & 83.1 & 2.44 \\
\hline Falenets & 4.9 & 5.8 & 0.41 & 0.00 & 9.2 & -0.83 & 5.34 & 222.2 & 4.45 \\
\hline $178 \mathrm{~h} 13$ & 5.2 & 10.0 & 1.88 & 2.15 & 32.9 & -4.89 & 7.60 & 128.9 & 3.83 \\
\hline $194 \mathrm{~h} 13$ & 5.4 & 8.4 & 1.30 & 0.19 & 23.7 & -2.96 & 6.88 & 139.3 & 4.26 \\
\hline 79h14 & 5.1 & 6.1 & -0.30 & 0.36 & 10.1 & -1.04 & 5.57 & 223.0 & 4.53 \\
\hline $245 \mathrm{~h} 14$ & 5.6 & 8.0 & 1.09 & 0.07 & 19.9 & -2.42 & 6.83 & 164.1 & 4.58 \\
\hline Argamak & 4.4 & 8.8 & 1.85 & 0.86 & 36.1 & -4.44 & 6.62 & 83.8 & 3.14 \\
\hline st. Krechet & 4.2 & 6.9 & 0.89 & 1.69 & 24.5 & -2.73 & 5.53 & 100.0 & 3.43 \\
\hline Average & 4.7 & 7.8 & 1.00 & 1.88 & 24.1 & -3.1 & 6.23 & 142.8 & 3.84 \\
\hline
\end{tabular}

This is confirmed by high variability $(\mathrm{V}=53.7 \%)$ and low resistance to stress $(-8.20)$. At the same time, this line has a high genetic flexibility (7.92). Among the studied set of genotypes of glumaceous oat, the Falenets variety had the greatest resistance to stress (0.83 ) with a stability index $\left(\mathrm{Si}^{2}=0.00\right)$ and a coefficient of variation $\mathrm{V}=9.2 \%$. It should be noted its high breeding value (4.45) and stability relative to the Krechet standard (ILVS $=222.2 \%$ ). According to the totality of indicators, Falenets refers to varieties that can form a high harvesting of dry matter in changing environmental conditions, with a minimum of costs.

Also, a high breeding value based on dry matter harvesting was observed in the lines $245 \mathrm{~h} 14$ (4.58), $79 \mathrm{~h} 14$ (4.53), high indicators of ILVS and stress resistance. The highyielding variety Medved (8.2 t/ha of dry matter) has high plasticity (1.57), the lowest stability of the presented varieties and lines (8.50) and low stress resistance (-5.27), as evidenced by the high level of the coefficient of variation $(\mathrm{V}=33.7 \%)$. Nevertheless, the 
variety showed high genetic flexibility (7.74), breeding value (4.05) and high stability relative to the standard (ILVS=152.6\%). According to the combination of these characteristics, this variety can be attributed to the group of high-intensity. The same group includes the Sapsan variety, which has low plasticity and an average level of stability, variation coefficient and resistance to stress. For the prospective $4 \mathrm{~h} 14$ line, high resistance to stress $(-0.90)$, stability $\left(\mathrm{Si}^{2}=0.01\right)$, ILVS $=184.7 \%$ and a low variation coefficient (V=9.8\%) were established.

There was a highly positive relation between the dry matter harvesting with the regression coefficient (bi) $(\mathrm{r}=0.83)$, the stability index $\left(\mathrm{Si}^{2}\right)(\mathrm{r}=0.75)$, genetic flexibility $(\mathrm{r}=0.98)$, the variation coefficient $(\mathrm{r}=0.79)$ and negative with stress resistance $(\mathrm{r}=-0.85)$.

Grain yield is the most important indicator of feed productivity. The most valuable varieties are those that can produce high yields of grain and green mass in various environmental conditions. For a more complete characteristic of the variety, its assessment is carried out according to the parameters of adaptability and phenotypic stability. The most favorable conditions for the formation of a high grain yield were formed in 2019, which was facilitated by warm weather with moderate precipitation during the "paniculation ripening" period $(\mathrm{HTC}=1.4)-7.5 \mathrm{t} / \mathrm{ha}$, which is confirmed by the environmental conditions index $\mathrm{Ii}=1.35$. The low temperature throughout the growing season and excessive moisture in June $(\mathrm{HTC}=2.06)$ contributed to its lengthening to 96 days. Drier and hotter weather in 2020 led to a reduction in the growing season to 84 days, and the yield was $5.7 \mathrm{t} / \mathrm{ha}$ ( $\mathrm{Ii}=-$ 0.51 ). In the limited conditions of 2018 , against the background of low temperatures and excessive moisture during the formation of grain, lodging and the development of diseases, uneven ripening of crops and an increase in the duration of the harvesting period were noted, which negatively affected the yield, which averaged $5.4 \mathrm{t} / \mathrm{ha}$ for genotypes ( $\mathrm{Ii}=-$ $0.84)$.

Grain yield strongly depended on the duration of the growing season from germination to maturation $(\mathrm{r}=0.70$ at $\mathrm{p} \leq 0.05)$. Temperature $(\mathrm{r}=0.48)$ and precipitation $(\mathrm{r}=0.46)$ had a positive average influence on the formation of grain yield during the research period, and a significant negative indicator of the state of agro-climatic resources (HTC) for the entire growing season $(\mathrm{r}=-0.71)$. In its turn, a significant negative relation was noted between the HTC for the entire growing season and the duration of the interphase period "paniculation ripening" ( $\mathrm{r}=-0.88)$, as well as the period "sprouting - maturation" $(\mathrm{r}=-0.94)$.

The best combination of plasticity and stability in grain yield was observed in the Falenets variety and lines $4 \mathrm{~h} 14,178 \mathrm{~h} 13$, where the plasticity index (bi) varied from 1.13 to 2.00 , while the stability index $\left(\mathrm{Si}^{2}\right)$ was equal to or close to zero (Table 3 ). These genotypes are responsive to the improvement of environmental conditions and are able to form a stable crop when they deteriorate. The high-yielding Medved variety (6.87 t/ha) and the $325 \mathrm{~h} 12$ line (6.94 t/ha) have high plasticity (bi=1.91 and 1.06, respectively) and fairly high stability $\left(\mathrm{Si}^{2}=0.44\right.$ and 0.25 , respectively). The promising line $79 \mathrm{~h} 14\left(\mathrm{bi}=1.37 ; \mathrm{Si}^{2}=1.16\right)$, as well as the Argamak variety $\left(\mathrm{bi}=1.16 ; \mathrm{Si}^{2}=1.14\right.$ ), is characterized by a positive reaction to the improvement of growing conditions according to the regression coefficient, but does not give a stable yield under stress, which allows them to be attributed to the high-intensity group. Having high stability and low plasticity, the Krechet variety and the 194h13 line are able to form stable yields in changing and unfavorable environmental conditions with minimum costs.

The ability of the variety to realize its genetic potential when conditions deviate from the norm can be estimated by the homeostasis indicator (Hi). The varieties Medved and Krechet, lines $325 \mathrm{~h} 12,79 \mathrm{~h} 14$, and $178 \mathrm{~h} 13$, have the highest, above average homeostaticity. The remaining genotypes with the same limiting environmental factors are more variable in terms of grain yield. 
Table 3. Parameters of ecological adaptability and plasticity of glumaceous oat varieties on the basis of "grain yield", 2018-2020.

\begin{tabular}{|c|c|c|c|c|c|c|c|c|c|}
\hline \multirow{2}{*}{$\begin{array}{l}\text { Variety, } \\
\text { line }\end{array}$} & \multicolumn{3}{|c|}{ Grain yield, $\mathrm{t} / \mathrm{ha}$} & \multirow[t]{2}{*}{$\mathrm{b}_{\mathrm{i}}$} & \multirow[t]{2}{*}{$\mathrm{Si}_{\mathrm{i}}^{2}$} & \multirow[t]{2}{*}{$\mathrm{Hi}$} & \multirow{2}{*}{$\begin{array}{l}\mathrm{V}, \\
\%\end{array}$} & \multirow{2}{*}{$\begin{array}{c}\text { Resistance } \\
\text { to stress }\end{array}$} & \multirow{2}{*}{$\begin{array}{c}\text { Genetic } \\
\text { flexibility }\end{array}$} \\
\hline & $\mathrm{X}_{\lim }$ & $\mathrm{X}_{\mathrm{opt}}$ & $\mathrm{X}$ & & & & & & \\
\hline $46 \mathrm{~h} 14$ & 4.44 & 7.15 & 6.04 & 0.68 & 2.75 & -0.69 & 23.5 & -2.71 & 5.80 \\
\hline $4 \mathrm{~h} 14$ & 5.22 & 7.74 & 6.23 & 1.13 & 0.01 & -0.07 & 21.3 & -2.52 & 6.48 \\
\hline Sapsan & 4.79 & 6.46 & 5.89 & 0.51 & 1.08 & -0.83 & 16.1 & -1.67 & 5.63 \\
\hline Medved & 4.84 & 9.37 & 6.87 & 1.91 & 0.44 & 1.78 & 33.5 & -4.53 & 7.11 \\
\hline $325 \mathrm{~h} 12$ & 5.74 & 8.31 & 6.94 & 1.06 & 0.25 & 2.55 & 18.6 & -2.57 & 7.03 \\
\hline Falenets & 4.92 & 9.20 & 6.48 & 2.00 & 0.03 & 0.26 & 36.5 & -4.28 & 7.06 \\
\hline $178 \mathrm{~h} 13$ & 5.15 & 7.69 & 6.12 & 1.16 & 0.00 & 0.49 & 22.4 & -2.54 & 6.42 \\
\hline 194h13 & 5.86 & 6.93 & 6.27 & 0.47 & 0.05 & 0.41 & 9.2 & -1.07 & 6.40 \\
\hline $79 \mathrm{~h} 14$ & 5.03 & 8.51 & 6.54 & 1.37 & 1.16 & 0.75 & 27.3 & -3.48 & 6.77 \\
\hline $245 \mathrm{~h} 14$ & 4.86 & 5.98 & 5.46 & -0.01 & 0.63 & -2.25 & 10.3 & -1.12 & 5.42 \\
\hline Argamak & 4.21 & 7.30 & 5.86 & 1.16 & 1.14 & -2.24 & 26.5 & -3.09 & 5.76 \\
\hline st. Krechet & 5.26 & 6.78 & 6.09 & 0.56 & 0.32 & 0.83 & 12.6 & -1.52 & 6.02 \\
\hline Average & 5.03 & 7.62 & 6.23 & 1.00 & 0.65 & 0.08 & 21.5 & -2.59 & 6.32 \\
\hline
\end{tabular}

Among the studied genotypes, the most stress-resistant lines were $194 \mathrm{~h} 13(-1.07)$ and $245 \mathrm{~h} 14(-1.12)$, the variability $(\mathrm{V}, \%)$ of these varieties was 9.2 and $10.3 \%$, respectively. The Medved and Krechet varieties were characterized by significant variability and low resistance to stress. At the same time, they, like the $325 \mathrm{~h} 12$ line, were characterized by a high degree of compliance of the studied trait with environmental conditions, as evidenced by the indicator of genetic flexibility, which means that these genotypes have a high degree of responsiveness to improving cultivation conditions.

The studies showed a high degree of positive dependence of grain yield with the stability index $\left(\mathrm{Si}^{2}\right)(\mathrm{r}=0.71)$, genetic flexibility $(\mathrm{r}=0.94)$, regression coefficient $\left(\mathrm{b}_{\mathrm{i}}\right)(\mathrm{r}=0.71)$ and a negative dependence with stress resistance $(\mathrm{r}=-0.61)$.

\section{Conclusion}

Varieties and lines of glumaceous oat that combine high grain yield and high-quality dry matter are identified. Under favorable environmental conditions, the variety of the universal feed direction of the high-intensity Medved type is able to form a high yield of grain (6.87 $\mathrm{t} / \mathrm{ha}$ ), green mass $(34.9 \mathrm{t} / \mathrm{ha})$ and dry matter $(8.2 \mathrm{t} / \mathrm{ha})$. According to the indicator "harvesting of dry matter", the Medved variety showed high genetic flexibility (7.74) and breeding value $(\mathrm{Sc}=4.05)$. Similar characteristics are noted in the perspective line $325 \mathrm{~h} 12$. The lines of the mowing direction $178 \mathrm{~h} 13$ and $245 \mathrm{~h} 14$ were identified, the yield of the green mass of which was $40.1 \mathrm{t} / \mathrm{ha}$ and $24.9 \mathrm{t} / \mathrm{ha}$, the harvesting of dry matter was $7.5 \mathrm{t} / \mathrm{ha}$ and $6.6 \mathrm{t} / \mathrm{ha}$, respectively. At the same time, the $245 \mathrm{~h} 14$ line showed high plasticity (bi=1.09) and stability $(\mathrm{Si}=0.07)$, including relative to the Krechet standard (ILVS=164.1\%), and high breeding value ( $\mathrm{Sc}=4.58)$, had a high content of raw fat in dry matter $(2.8 \%)$. According to dry matter harvesting, the varieties of the extensive type include Sapsan, Falenets and Krechet. According to the set of characteristics (low plasticity, high stability and resistance to stress) these varieties are able to form a stable dry matter harvesting in adverse environmental conditions with minimum costs. The varieties Sapsan and Krechet among the studied set of genotypes were distinguished by a high content of crude protein in dry matter (11.9 and $11.3 \%$, respectively). 


\section{References}

1. M.V. Tulyakova, G.A. Batalova, S.V. Permyakova, E.M. Lisitsyn, Achievements of Science and Technology of AIC, 32(8), 54 (2018) DOI: 10.24411/0235-2451-201810814.

2. L.S. Nikolaeva, V.E. Kardashina, Agro-Industrial Complex of Russia 23(2), 300 (2016).

3. M.Y. Lodhi, I.B. Marghazani, K. Hamayun, M.J. Marri, J. Anim. Plant Sci., 19(1), 34 (2009)

4. L.S. Nikolaeva, V.E. Kardashina, Agro-Industrial Complex of Russia, 24(3), 618 (2017)

5. N. I. Kashevarov, V. A. Vjazovsky, Achievements of Science and Technology of AIC, 11, 42 (2010)

6. I.G. Loskutov, T.V. Shelenga, A.V. Konarev, A.L. Shavarda, E.V. Blinova, N.I. Dzubenko, Vavilov Journal of Genetics and Breeding, 20(5), 636-642 (2016). DOI: 10.18699//VJ16.185.

7. V.E. Kardashina, L.S. Nikolaeva, Achievements of Science and Technology of AIC, 34(5), 56-60 (2020). DOI: 10.24411/0235-2451-2020-10511.

8. 8 O. Bilgin, C. Guzman, I. Baser, J. Crossa, K.Z. Korkut. Crop Sci. 56(1), 73-84 (2016).

9. Method of state variety testing of crops, 267 (Moscow: Kolos, 1985)

10. V.Z. Pakudin, L.M. Lopatina, Agricultural biology, 4, 109 (1984)

11. Rosielle A.A., Hamblin J. Crop Sci. 21(6), 943 (1981)

12. Plokhinsky N.A. Biometrics (Novosibirsk, 1961)

13. G.T. Selyaninov, Works on agricultural meteorology 20, 165 (1928)

14. S.P. Martynov, Agricultural biology 3, 124 (1989)

15. E.D. Nettevich, A.I. Morgunov, M.I. Maximenko, Vestnik of the Russian agricultural science 1, 66 (1985)

16. V.V. Khangildin, Genetics of quantitative features of agricultural plants, 111 (Moscow: Nauka Publ, 1978)

17. G. A. Batalova, Oats in the Volga-Vyatka region (Kirov: Orma LLC, 2013)

18. F.A. Nehvi, Shafiq A. Wani, Hussain Altaf, M.I. Maqhdoomi, B.A Allai., Wassem Yousuf, F.A. Bahar, Z.A. Dar, Asian J. Plant Sci. 6(4), 628 (2007)

19. T.M. Slobodyanik, V.M. Sayapina, Fodder Production 12, 16 (2010)

20. K.A. Singh, L.N. Singh, Indian J. Hill Farm. 5(2), 133 (1992)

21. G.P. Maysak, V.A. Voloshin, Modern problems of sustainable construction of agricultural landscapes and resource-saving technologies in agriculture in the NorthEast region of the European part of Russia, 144 (Perm: OT i DO Publ., 2009) 